\title{
Growth Hormone Deficiency in Congenital Toxoplasmosis
}

\author{
Juma Natsheh ${ }^{1}$ Bassam Abu-Libdeh ${ }^{1}$ Abdulsalam Abu-Libdeh ${ }^{1}$ \\ ${ }^{1}$ Department of Pediatrics, Endocrinology Unit, Makassed Islamic \\ Hospital, Jerusalem, Israel \\ J Child Sci 2018;8:e43-e45.

\begin{abstract}
Address for correspondence Abdulsalam Abu-Libdeh, MD, Department of Pediatrics, Endocrinology Unit, Makassed Islamic Hospital, Al-Quds University, P.O.B. 19482, Mount of Olives, Jerusalem, Israel (e-mail: draabulibdeh@hotmail.com).
\end{abstract}

\author{
Abstract \\ Keywords \\ - congenital \\ toxoplasmosis \\ - hypo- \\ thalamopituitary \\ dysfunction \\ - growth hormone \\ deficiency
}

Congenital toxoplasmosis represents the second most commonly recognized congenital infection. Ocular and neurological abnormalities are considered the most frequent sequelae. Endocrinological manifestations are rare and have received little attention. We report a 3.5-month-old female infant who presented with failure to thrive and recurrent hypoglycemic attacks, diagnosed as growth hormone deficiency due to sequelae of congenital toxoplasmosis. Although endocrinological sequelae of congenital toxoplasmosis are uncommon, they represent potentially treatable conditions. Here, we stress on the importance of monitoring pituitary function and growth in children in particular, with congenital toxoplasmosis, keeping in mind other possible, potentially treatable, endocrinological manifestations.

\section{Introduction}

Congenital toxoplasmosis, although rare, is characterized by a meningoencephalitis with intense perivascular inflammation involving particularly the basal ganglia and periventricular regions. It is likely that important hypothalamic regulatory centers are involved in this process resulting in hypothalamo-pituitary dysfunction. Inspite of this, very little is known about this aspect of the disease. Currently, it represents the second most commonly recognized congenital infection. ${ }^{1}$ Toxoplasma gondii is an apicomplexan parasite that replicates in cells and tissues, especially in the brain and eye. ${ }^{2}$ It infects birds and many mammals, especially felines, worldwide. Human infection results from ingestion of meats containing viable $T$. gondii tissue cysts, foods, water, and garden soils contaminated with oocysts, or through congenital transplacental transmission of rapidly replicating tachyzoites from mothers, who become infected during pregnancy (e.g., by changing the cat litter) and pass the infection to the fetus. ${ }^{1,3}$ About 5 per 1,000 nonimmune pregnant women may acquire toxoplasma infection, with a 10 to $100 \%$ risk of transmission to the baby. ${ }^{4}$

received

June 19, 2017

accepted after revision

April 18, 2018
Early clinical manifestations appearing in the neonatal period include jaundice, hepatomegaly, splenomegaly, rash, intrauterine growth retardation, microcephaly, hydrocephalus, and chorioretinitis. ${ }^{1}$

Ocular and neurological abnormalities such as micro- or macrocephaly, psychomotor retardation, and seizures are possible outcomes, and considered the most frequent sequelae of congenital toxoplasmosis. ${ }^{3,5-7}$ Endocrine manifestations are extremely uncommon and received little attention.

Here, we describe a Palestinian patient with congenital toxoplasmosis and growth hormone deficiency.

\section{Case Report}

A 3.5-month-old female infant was born to nonconsanguineous Palestinian parents with an uneventful pregnancy and delivery. She had been hospitalized at 1 month of age as she developed hematoma at site of routine vaccine puncture. Initial investigations showed prolonged prothrombin time (PT), partial thromboplastin time (PTT), and high international normalized ratio (INR), managed with vitamin $\mathrm{K}$ and fresh frozen plasma, in addition to history of hypoglycemia during hospitalization. The patient was readmitted at
DOI https://doi.org/

10.1055/s-0038-1655752. ISSN 2474-5871.
Copyright $\odot 2018$ Georg Thieme Verlag KG Stuttgart · New York
License terms

(요 (1) $\Theta \circledast$ 
3 months of age with the same clinical picture, prolonged PT, PTT, and high INR. Her examination revealed failure to thrive, delayed developmental milestones, and jaundice. Investigations revealed slightly elevated transaminases and direct hyperbilirubinemia. TORCH screening using microparticle enzyme immunoassay method showed toxoplasmosis immunoglobulin $\mathrm{M}$ (IgM) positive (qualitative) and $\operatorname{IgG}$ $>300 \mathrm{IU} / \mathrm{mL}$. Checking the mother showed toxoplasmosis IgM was positive and $\operatorname{IgG}>300 \mathrm{IU} / \mathrm{mL}$ (-Table 1). Liver biopsy was done and showed portal and parenchymal inflammation and one microgranuloma, features compatible with toxoplasmosis. She was diagnosed to have congenital toxoplasmosis, and treatment with pyrimethamine, sulfadiazine, and leucovorin (folinic acid) was initiated. Ophthalmic examination was normal with no evidence of chorioretinitis, and brain computed tomography (CT) scan showed no intracranial or periventricular calcifications. Unfortunately, head MRI was not done.

During hypoglycemia episodes, critical sample was taken, which showed low growth hormone, normal cortisol response, and low insulin level. Screening of other pituitary hormones was interpreted as normal. She was diagnosed to have growth hormone deficiency and was started on growth hormone during which she showed a significant improvement, no hypoglycemic attacks, improvement in liver transaminases level and normalization of PT, PTT, and INR.

Table 1 Relevant laboratory results of the patient as compared with the normal ranges

\begin{tabular}{|c|c|c|}
\hline Laboratory test & Result & $\begin{array}{l}\text { Normal } \\
\text { ranges }\end{array}$ \\
\hline Alanine transaminase & $53 \mathrm{IU} / \mathrm{L}$ & $(0-34)$ \\
\hline Aspartate transaminase & $134 \mathrm{IU} / \mathrm{L}$ & $(0-31)$ \\
\hline Alkalinephosphatase & $471 \mathrm{IU} / \mathrm{L}$ & $(42-98)$ \\
\hline Total bilirubin & $7.8 \mathrm{mg} / \mathrm{dL}$ & $(0-1.2)$ \\
\hline Direct bilirubin & $4.4 \mathrm{mg} / \mathrm{dL}$ & $(0-0.4)$ \\
\hline Prothrombin time & 18.9 seconds & \\
\hline $\begin{array}{l}\text { Partial thromboplastin } \\
\text { time }\end{array}$ & 67 seconds & $(24-36)$ \\
\hline $\begin{array}{l}\text { International normalized } \\
\text { ratio }\end{array}$ & 2.37 & \\
\hline Growth hormone $^{a}$ & $5.6 \mathrm{ng} / \mathrm{mL}$ & \\
\hline Cortisol $^{a}$ & $16.3 \mu \mathrm{g} / \mathrm{dL}$ & $(3-17)$ \\
\hline Insulin ${ }^{a}$ & $<0.1 \mathrm{mIU} / \mathrm{mL}$ & \\
\hline $\begin{array}{l}\text { Follicle-stimulating } \\
\text { hormone }\end{array}$ & $0.1 \mathrm{mlU} / \mathrm{mL}$ & \\
\hline Luteinizing hormone & $<0.1 \mathrm{mlU} / \mathrm{mL}$ & \\
\hline $\begin{array}{l}\text { Thyroid-stimulating } \\
\text { hormone }\end{array}$ & $4.5 \mu \mathrm{lU} / \mathrm{mL}$ & $(0.4-4)$ \\
\hline Free T4 & $1.2 \mathrm{ng} / \mathrm{dL}$ & $(0.8-2)$ \\
\hline Toxo immunoglobulin M & Positive & Qualitative \\
\hline Toxo immunoglobulin G & $>300 \mathrm{IU} / \mathrm{mL}$ & $(<3 \mathrm{IU} / \mathrm{mL})$ \\
\hline
\end{tabular}

${ }^{\mathrm{a} D u r i n g}$ hypoglycemic attack.

\section{Discussion}

Toxoplasma gondii is an extremely widespread, and thus successful, protozoan with a complex lifecycle. Once it enters the body, T. gondii traverses the intestinal or placental epithelium as a free parasite by paracellular transmigration and enters circulating cells such as macrophages or dendritic cells. It then appears to use such cells as a "Trojan horse" to gain access to privileged sites such as the brain. In vitro studies using mouse brain cells have demonstrated that tachyzoites invade microglia, astrocytes, and neurons, and the parasite thereafter forms cysts within these cells. ${ }^{3}$ Congenital toxoplasmosis is characterized by a meningoencephalitis with intense perivascular inflammation involving particularly the basal ganglia and periventricular regions. ${ }^{5,8}$ Intracranial calcifications tend to be scattered diffusely throughout the brain parenchyma. ${ }^{1}$ The effect of the infection on brain is caused by the direct destruction of cells by T. gondii and the inflammatory cytokine-mediated immune response mounted against the infection trying to control it; moreover, it is known that intracellular T. gondii tachyzoites manipulate a variety of signal transduction pathways related to apoptosis, antimicrobial effector mechanisms, and immune cell maturation. It is likely that important hypothalamic regulatory centers are involved in this process resulting in hypothalamo-pituitary dysfunction. ${ }^{5,8}$ On infected mice with toxoplasmosis and thyroid dysfunction, Stahl and Kaneda ${ }^{9}$ showed that the locus of this thyroid dysfunction was in the hypothalamus leading to inadequate pituitary function.

Although congenital toxoplasmosis is a well-known cause of intrauterine growth retardation, postnatal growth and development have hardly been evaluated in these children and systematic endocrine studies have not been performed. ${ }^{8}$ Lopes et $\mathrm{al}^{6}$ reported a case of congenital toxoplasmosis and "pituitary dwarfism" back in 1955 . Massa et al $^{5}$ reported three cases of congenital toxoplasmosis and hypothalamo-pituitary dysfunction. Suresh Babu et $\mathrm{al}^{8}$ reported hypogonadotropic hypogonadism. Others reported precocious puberty, central diabetes insipidus, and congenital myxedema. ${ }^{5,8,10}$ Around 150 cases have been reported in literature so far. ${ }^{8}$

The patient presented with two seemingly unrelated problems, the first being her liver dysfunction that was shown to be the result of congenital toxoplasmosis as confirmed by serology and liver biopsy. Second, she had hypoglycemic attacks. Pyrimethamine, sulfadiazine, and leucovorin have been given to the infant and none of these has ever caused hypothalamic-pituitary dysfunction as per available literature and research. Hormonal studies revealed growth hormone deficiency, after which correction resulted in stabilization of blood glucose levels with no more hypoglycemic attacks. Growth hormone has been shown to modulate bile acid synthesis and secretion, as it increases the hepatobiliary secretion of bile acids, so deficiency of pituitary hormones may be related to the pathogenesis of cholestasis by promoting the accumulation of bile acid precursor and producing a cholestatic effect. Hence, treatment with growth hormone will improve liver function. Although ophthalmic examination and brain CT were normal, we think that the congenital 
toxoplasmosis diagnosed in the patient is the reason behind her pituitary dysfunction manifested as growth hormone deficiency. The pituitary dysfunction here was partial as other hormones were within normal ranges.

Among other abnormalities and sequelae, endocrinological disturbances in congenital toxoplasmosis have received little attention throughout years, despite the fact that they are treatable conditions. At the present time, we cannot draw definite conclusions on the incidence of endocrinological disturbances in children with congenital toxoplasmosis, as few cases are reported so far relative to other complications. 5

In conclusion, congenital toxoplasmosis should be considered as one of the organic causes during evaluating children with pituitary disturbances. However, endocrinological conditions should be considered as a possible complication and late sequelae. We recommend that growth should be monitored carefully as well as other pituitary functions in those children with congenital toxoplasmosis.

\section{Conflict of Interest}

None.

\section{References}

1 Bale JF Jr. Fetal infections and brain development. Clin Perinatol 2009;36(03):639-653

2 McLeod R, Kieffer F, Sautter M, Hosten T, Pelloux H. Why prevent, diagnose and treat congenital toxoplasmosis? Mem Inst Oswaldo Cruz 2009;104(02):320-344

3 Carruthers VB, Suzuki Y. Effects of Toxoplasma gondii infection on the brain. Schizophr Bull 2007;33(03):745-751

4 Kravetz J. Congenital toxoplasmosis. BMJ Clin Evid 2008;2008:906

5 Massa G, Vanderschueren-Lodeweyckx M, Van Vliet G, Craen M, de Zegher F, Eggermont E. Hypothalamo-pituitary dysfunction in congenital toxoplasmosis. Eur J Pediatr 1989;148(08):742-744

6 Lopes FM, Gonçalves DD, Mitsuka-Breganó R, Freire RL, Navarro IT. Toxoplasma gondii infection in pregnancy. Braz J Infect Dis 2007;11(05):496-506

7 Wolfe SM, Sawitz WG, Paschkis KE. Pituitary dwarfism and toxoplasmosis. J Clin Endocrinol Metab 1955;15(06):745-753

8 Suresh Babu PS, Nagendra K, Navaz RS, Ravindranath HM. Congenital toxoplasmosis presenting as hypogonadotropic hypogonadism. Indian J Pediatr 2007;74(06):577-579

9 Stahl W, Kaneda Y. Aetiology of thyroidal dysfunction in murine toxoplasmosis. Parasitology 1998;117(Pt 3):223-227

10 Nitta A, Suzumura H, Kano K, Arisaka O. Congenital toxoplasmosis complicated with central diabetes insipidus in the first week of life. J Pediatr 2006;148(02):283 